\title{
Indonesian EFL Students' Motivation in English Learning and their Literacy Skills across Gender
}

\author{
Sawitri Agustrianti (Corresponding author) \\ Universitas Negeri Malang, East Java, Indonesia \\ E-mail: sawitri_agustrianti@yahoo.com \\ Bambang Yudi Cahyono \\ Universitas Negeri Malang, East Java, Indonesia \\ E-mail: yudic2000@yahoo.com \\ Ekaning Dewanti Laksmi \\ Universitas Negeri Malang, East Java, Indonesia \\ E-mail: laksmiindonesia1@gmail.com
}

$\begin{array}{lll}\text { Received: 05-03-2016 } & \text { Accepted: 14-05-2016 } & \text { Advance Access Published: May 2016 } \\ \text { Published: 01-07-2016 } & \text { doi:10.7575/aiac.ijalel.v.5n.4p.219 } & \text { URL: http://dx.doi.org/10.7575/aiac.ijalel.v.5n.4p.219 }\end{array}$

\begin{abstract}
Motivation and gender are claimed to have significant roles to the success of language learning, particularly in literacy skills. This study examined the relationship of students' motivation in English learning and their literacy skills across gender. It involved 100 students enrolled in English Education Study Program, Tadulako University, Palu City, Central Sulawesi Province, Indonesia. Data were collected through questionnaire on motivation in English learning, reading comprehension test, and writing test. The analysis from Spearman rank correlation and independent sample t-test revealed that there were high positive correlations between students' motivation and literacy skills; and high positive correlations between students' achievement scores in reading and writing skills. It indicates that when the students had high motivation, they had better scores in their literacy skills. In addition, when the students got high achievement scores in reading skill, their achievement in writing would like to follow suit. This study did not reveal any significant relationship between motivation and gender, as well as between literacy skills and gender.
\end{abstract}

Keywords: Motivation, Literacy skills, Gender

\section{Introduction}

The success of English language learning is not only a matter of teaching methods, but it also involves a number of factors. Individual factors like motivation and gender are frequently recognized as the potential factors influencing foreign language learning. Motivation has been widely accepted by both teachers and researchers as one of the key factors that influences the rate and success of second/foreign language learning (Dornyei, 1998). Motivation is the combination of intellectual or physical effort and emotional arousal to achieve a set of goals in language learning (Gardner, 1985; William \& Burden, 1997). It is considered as an important process or complex phenomenon whereby goal-directed activity is instigated and sustained in foreign language classroom to which the students make choices to pursue their learning goal (Dornyei, 2001; Lightbown \& Spada, 2006; Brown, 2007; Schunk, Pintritch, \& Meece, 2008). In brief, motivation is the students' willingness, impulse, or enthusiasm that involves the effort to achieve the goal in language learning.

Gender is also considered to have an impact on students' language learning process. Gender is a way of constructing notions of male and female from the social elaboration of biological sex (Eckert \& Ginet, 2003). It can be stated that gender deals with something that people do or perform in the society; it is not determined biologically, but it is socially constructed. In the context of English as a foreign language (EFL), researchers found some evidence of the influence of gender on the language learning. Some studies show the superiority of the female on language learning rather than male students (Lin, 2011; Mistar, 2014). Nevertheless, some studies also report the opposite results where males outperformed female students, or none of them have significant difference in terms of language learning achievement (Mahmud, 2010; Tahriri, 2011). The previous results provide rich insights for interpreting the gender issues in the studies of EFL. Numerous studies in line with motivation toward other affective factors, teaching strategies, and general English had been done by other researchers (Elias, 2010; Xu, 2011; Toni, 2012; Mobarakeh, 2014).

In Indonesia, the teaching of English at university level comprises the skills of listening, speaking, reading, and writing. The development of the literacy skills in particular, contributes to the students' academic achievement in EFL. A research report commissioned by Cambridge assessment (2013:11) asserts that the literacy is acquiring, creating, connecting, and communicating meaning in a wide variety of context. Therefore, literacy skills imply the skills in 
receptive, productive, and thinking process. Among the types of literacy skills in English, this study focuses on reading and writing skills. Reading is the ability to understand where the words have context and texts have meaning. A research report commissioned by Cambridge assessment (2013:11) explains reading as understanding, using, reflecting on and engaging with written texts, in order to achieve one's goal, to develop one's knowledge and potential to participate in society. It is a process at once to construct and to recognize the message of written language. It is emphasized that without the skills of reading to learn, students' academic progress will be limited. Equally important, writing skill is one of the main literacy skills of language. Writing is a process of discovery where a person can communicate a variety of messages to a close or far distance, known or unknown reader (Dietsch, 2009; Galko, 2002; Murcia, 2001). Thus, writing skill is the skill in expressing ideas, feeling, or thought in acceptable written English for a purpose, such as explaining events, describing an object or a process, and persuading other people by giving more attention on the use of language as correctly as possible.

In accordance with the background of the study, the research problems were formulated as follows:

1. Is there any relationship between students' motivation in English learning and students' scores in literacy skills?

2. Is there any relationship between students' scores in reading skill and students' scores in writing skill?

3. Is there any significant difference between English learning motivation of male and female students?

4. Is there any significant difference between literacy (reading and writing) skills of male and female students?

\section{Research Method}

This study employed correlation design and was conducted in English Education Study Program, Teacher Training and Education Faculty, Tadulako University, Palu city, Central Sulawesi province, Indonesia. A total of 100 students $(85$ females and 15 males) enrolled in the third semester participated in this study. Based on demographic information of the questionnaire, the range of students' age was not widely spread (18 to 21 years old) and they claimed to have almost the same length of time in learning English (beginning from junior high school, at the age of 12 - 15 years). Thus, they had relatively the same exposure to English language which makes their age and length of study was not controlled as variables in this study.

The data were collected through questionnaire on motivation in English learning, reading comprehension test, and writing test. The questionnaire was adapted from Attitude/Motivation Test Battery (AMTB) proposed by Gardner (1985). The questions were in the form of four-point Likert scales, ranging from strongly agree (4), agree (3), disagree (2), and strongly disagree (1). Middle point "Neither agree nor disagree" was not used in this study due to the aim of the study to see the students' tendency either to agreement or disagreement. The questionnaire on motivation in English learning consisted of 25 items. The questionnaire is shown in Appendix 1.

The type of reading comprehension test administered in this study contained objective and subjective test items. In objective test, the test taker gets the same mark no matter which examiner marks the test (Heaton, 1988:25). In other words, the test had a practicality in terms of the scoring process. The test consisted of matching items, passage comprehension, ordering tasks, and short answers. There were 20 items of reading comprehension test. The instructions were made as clear as possible to ensure that the students do not get confused in understanding the instruction of the reading test.

The writing test was in the form of paragraph construction task. The students were asked to write one recount paragraph. They had to pay attention to the content, sentence structure, time order signals, and correct punctuation. Analytical scoring rubric was used to measure students' achievement in writing skill. Analytic scoring was applied to capture its closer association with classroom language instruction (Brown, 2004:243).

The data from questionnaire on motivation in language learning were analyzed using descriptive statistics in order to know how many students belong to "high-motivated students" and "low-motivated students" categories. Two raters were involved in marking the students writing products. Inter rater agreement was conducted prior to the "real" rating process. The $r$ value is 0.906 which indicated a high level of agreement between the raters. Last, Spearman correlation using SPSS 16 was utilized to know the relationship between students' motivation in English learning and their scores in literacy skills; and to find out the relationship between students' scores in reading skill toward their scores in writing skill. Then, the difference in English learning motivation between male and female students; and the difference in literacy skills scores between male and female students were analyzed by conducting Independent Sample t-Test using SPSS 16.

\section{Results}

The results of the present study are organized in the order of the research questions.

\subsection{The relationship between students 'motivation in English learning and students'scores in literacy skills}

The writers examined the relationship between students' motivation and reading skill by using Spearman Rank Correlation. The result is shown in Table 1. 
Table 1. Correlation between Students' Motivation and Reading Skill

\begin{tabular}{lllll}
\hline \multirow{2}{*}{ Spearman's rho } & & Motivation & \multicolumn{1}{c}{ Reading } \\
\cline { 3 - 5 } & Motivation & Correlation Coefficient & 1.000 & .628 \\
& & Sig. (2-tailed) &. & .000 \\
& & $\mathrm{~N}$ & 100 & 100 \\
\cline { 2 - 5 } & Reading & Correlation Coefficient & .628 & 1.000 \\
& & Sig. (2-tailed) & .000 &. \\
& $\mathrm{~N}$ & 100 & 100 \\
\hline
\end{tabular}

As shown in Table 1, the sample of the study or $\mathrm{N}$ was 100 students, with the significant value (2-tailed) was 0.000 , which was lower than 0.05 . This showed that there was a significant correlation between the two variables. Next, the correlation coefficient $(r)$ was 0.628. Based on Cohen and Manion (1994, cited in Lodico et al., 2010: 284), this size of correlation showed moderately strong relationship between students' motivation in English learning and their achievement score in reading skill. The result of this study was supported by the study conducted by Tsujimoto (2015), which showed a strong positive correlation between motivation and reading value $(r=.723)$. However, a study by Olmez (2015) found different result that no significant correlation found between motivation and reading achievement $(r=.369)$. Despite the aforementioned previous studies, the finding of this study adds to the existing body of knowledge that the higher the students' motivation in learning English, the better the score they achieved in reading skill.

The writers examined the relationship between students' motivation and writing skill using Spearman Rank Correlation. The result is shown in Table 2.

Table 2. Correlation between Students' Motivation and Writing Skill

\begin{tabular}{lllll}
\hline & & Motivation & Writing \\
\hline Spearman's rho & Motivation & Correlation Coefficient & 1.000 & .756 \\
& & Sig. (2-tailed) &. & .000 \\
& & $\mathrm{~N}$ & 100 & 100 \\
\cline { 2 - 5 } & Writing & Correlation Coefficient & .756 & 1.000 \\
& & Sig. (2-tailed) & .000 &. \\
& $\mathrm{~N}$ & 100 & 100 \\
\hline
\end{tabular}

Based on Table 2, the significant value (2-tailed) was 0.000 , which was lower than 0.05 . It meant that there was also significant correlation between these two variables. Next, the correlation coefficient (r) was 0.756. Based on Cohen and Manion (1994, cited in Lodico, Spaulding, and Voegtle, 2010: 284), this size of correlation showed strong relationship between students' motivation in English learning and their achievement score in writing skill. The result of this study was in line with the study conducted by Hashemian and Heidari (2013), which showed positive correlation between motivation and writing skill $(r=.56)$. Nevertheless, a study by Williams and Alden (1983) found that $66.7 \%$ of the motivated students tend to place lower value in writing ability. Despite the aforementioned previous studies, the finding of this study enrich to the knowledge that the higher the students' motivation in learning English, the better the score they achieved in writing skill. Based on the aforementioned statistical results, the null hypothesis of the first research question was rejected. Therefore, the conclusion was that students' motivation in English learning is positively correlated with the students' achievement in literacy skills.

\subsection{The relationship between students'scores in reading and writing skills}

The students' scores in reading and writing skills were considered as the dependent variables. The writers examined the relationship between students' scores in reading and writing skills by using Spearman Rank Correlation. The result is shown in Table 3.

Table 3. Correlation of Students' Scores in Reading and Writing Skills

\begin{tabular}{lllll}
\hline & & Reading & \multicolumn{1}{l}{ Writing } \\
\hline \multirow{2}{*}{ Spearman's rho } & Reading & Correlation Coefficient & 1.000 & .817 \\
& & Sig. (2-tailed) &. & .000 \\
& & $\mathrm{~N}$ & 100 & 100 \\
\cline { 2 - 4 } & Writing & Correlation Coefficient & .817 & 1.000 \\
& & Sig. (2-tailed) & .000 &. \\
& $\mathrm{~N}$ & 100 & 100 \\
\hline
\end{tabular}


As shown in Table 3, with 100 students as the sample of the study, the significant value (2-tailed) was 0.000 , which was lower than 0.05, showing that there was correlation between the two variables. Meanwhile, the correlation coefficient between reading and writing was 0.817. Based on Cohen and Manion (1994, cited in Lodico et al., 2010: 284), this size of correlation showed strong relationship between students' scores in reading and writing skills. The result of this study conformed to the study conducted by Yoshimura (2009), who found that $71 \%$ of forty students answered reading before writing helps their writing skill by using information in the text. However, a study by Carson et al. (1990) indicated the weak relationship between reading and writing skill $(r=.271)$. In spite of the differences from previous studies, the result of the present study contributed to the body of knowledge that the higher score the students had in reading skill, the higher score they would get in writing skill. Therefore, the null hypothesis of the second research question was rejected. In conclusion, students' score in reading skill was positively correlated with students' score in writing skill.

\subsection{The relation of English learning motivation between male and female students}

In this study, gender was another variable which appeared as the moderator variable in terms of students' motivation. Next, the writers investigated the relation of English learning motivation between male and female students through independent sample t-test using SPSS 16.

Table 4. Group Statistics

\begin{tabular}{llllll}
\hline & Gender & $\mathrm{N}$ & Mean & Std. Deviation & Std. Error Mean \\
\hline Motivation Score & Female & 85 & 65.40 & 5.963 & .647 \\
& Male & 15 & 63.67 & 6.466 & 1.670 \\
\hline
\end{tabular}

Table 5. Independent Samples Test

\begin{tabular}{|c|c|c|c|c|c|c|c|c|c|c|}
\hline & & \multicolumn{4}{|c|}{$\begin{array}{c}\text { Levene's Test for } \\
\text { Equality of Variances }\end{array}$} & \multicolumn{5}{|c|}{ t-test for Equality of Means } \\
\hline & & \multirow[b]{2}{*}{$\mathrm{F}$} & \multirow[b]{2}{*}{ Sig. } & \multirow[b]{2}{*}{$\mathrm{t}$} & \multirow[b]{2}{*}{$\mathrm{df}$} & \multirow{2}{*}{$\begin{array}{l}\text { Sig. (2- } \\
\text { tailed) }\end{array}$} & \multirow{2}{*}{$\begin{array}{c}\text { Mean } \\
\text { Difference }\end{array}$} & \multirow{2}{*}{$\begin{array}{l}\text { Std. Error } \\
\text { Difference }\end{array}$} & \multicolumn{2}{|c|}{$\begin{array}{l}95 \% \text { Confidence } \\
\text { Interval of the } \\
\text { Difference }\end{array}$} \\
\hline & & & & & & & & & Lower & Upper \\
\hline \multirow[t]{2}{*}{$\begin{array}{l}\text { Motivation } \\
\text { Score }\end{array}$} & $\begin{array}{l}\text { Equal variances } \\
\text { assumed }\end{array}$ & .020 & .887 & 1.025 & 98 & .308 & 1.733 & 1.691 & -1.622 & 5.089 \\
\hline & $\begin{array}{l}\text { Equal variances } \\
\text { not assumed }\end{array}$ & & & .968 & 18.448 & .346 & 1.733 & 1.790 & -2.022 & 5.488 \\
\hline
\end{tabular}

As shown in Table 4, 100 students ( 85 female and 15 male) filled out the questionnaire. Next, the table showed the mean and standard deviation scores for female students were $\mathrm{M}=65.40, \mathrm{SD}=5.9$, and the mean and standard deviation scores for male students were $\mathrm{M}=63.6, \mathrm{SD}=6.46$. It is pictured clearly that the mean scores of female students were higher than male students even though the difference was not too high. Further, as presented in Table 5 , with the 0.05 level of significance, the sig. (2-tailed) value was 0.308 which was higher than 0.05 . The result of this study was supported by Yeung, Lau, and Nie (2011) who found that both male and female students had consistently higher motivation in learning English. However, a study by Hakan and Munire (2014) showed contrasting result that motivation level between male and female students was significantly different. Despite the difference on the previous studies, the finding of the present study showed that male and female students' motivation in English learning was at the same level for this sample Accordingly, the null hypothesis of the third research question was accepted. There was no significant difference in English learning motivation between male and female students.

\subsection{The relation of literacy skills (reading and writing) scores between male and female students}

The writers investigated the relation of literacy skills scores of male and female students through independent sample ttest using SPSS 16. 
Table 6. Group Statistics

\begin{tabular}{llllll}
\hline & Gender & $\mathrm{N}$ & Mean & Std. Deviation & Std. Error Mean \\
\hline Literacy Skills & Female & 85 & 75.55 & 11.267 & 1.222 \\
& Male & 15 & 72.95 & 16.899 & 4.363 \\
\hline
\end{tabular}

Table 7. Independent Samples Test

\begin{tabular}{|c|c|c|c|c|c|c|c|c|c|c|}
\hline & & $\begin{array}{l}\text { Leve } \\
\text { Equali }\end{array}$ & $\begin{array}{l}\text { ne's Test for } \\
y \text { of Variances }\end{array}$ & & & t-tes & st for Equalit & ty of Means & & \\
\hline & & \multirow[b]{2}{*}{$\mathrm{F}$} & \multirow[b]{2}{*}{ Sig. } & \multirow[b]{2}{*}{$\mathrm{t}$} & \multirow[b]{2}{*}{$\mathrm{df}$} & \multirow{2}{*}{$\begin{array}{l}\text { Sig. (2- } \\
\text { tailed) }\end{array}$} & \multirow{2}{*}{$\begin{array}{c}\text { Mean } \\
\text { Difference }\end{array}$} & \multirow{2}{*}{$\begin{array}{l}\text { Std. Error } \\
\text { Difference }\end{array}$} & \multicolumn{2}{|c|}{$\begin{array}{l}95 \% \text { Confidence } \\
\text { Interval of the } \\
\text { Difference }\end{array}$} \\
\hline & & & & & & & & & Lower & Upper \\
\hline \multirow[t]{2}{*}{$\begin{array}{l}\text { Literacy } \\
\text { Skills }\end{array}$} & $\begin{array}{l}\text { Equal variances } \\
\text { assumed }\end{array}$ & 3.589 & .061 & .760 & 98 & .449 & 2.603 & 3.425 & -4.195 & 9.401 \\
\hline & $\begin{array}{l}\text { Equal variances } \\
\text { not assumed }\end{array}$ & & & .574 & 16.266 & .574 & 2.603 & 4.531 & -6.990 & 12.196 \\
\hline
\end{tabular}

As presented in Table 6, the sample of the study or $\mathrm{N}$ was 100 , with 85 female and 15 male students did the literacy tests (reading and writing). Next, the table showed the mean and standard deviation scores for female students were $\mathrm{M}=75.55, \mathrm{SD}=11.26$; and the mean and standard deviation scores for male students were $\mathrm{M}=72.95, \mathrm{SD}=16.89$. Based on this computation, female students' literacy scores were higher than male students' scores even though it was only a slight difference. Further, as presented in Table 7, with the 0.05 level of significance, the sig. (2-tailed) value was 0.449 which was higher than 0.05 . The result of this study was in line to the result of a study conducted by Kasriri (2015) that presented no significant difference between two genders in their English skills performance. However, a study by Gorjian and Javadifar (2013) found different result that male students performed better in reading comprehension compared to female students. The finding of the present study highlighted that male and female students' achievement scores in literacy skills (reading and writing) were at the same level for this sample. Based on the aforementioned statistical results that sig. (2-tailed) $0.449>0.05$, the null hypothesis of the forth research question was accepted. There was no significance difference of students' literacy scores between male and female students.

\section{Discussion}

The discussions present the interpretations from the results of the present study and comparing them with the results of previous studies and related theories.

\subsection{The relationship between students' motivation in English learning and literacy skills}

Based on the results, the significance value of students' motivation in English learning and reading skill was 0.628. The value showed that motivation and reading skill had moderately strong relationship. This typical range of correlation coefficients might be useful for making prediction that when students were motivated in English learning, they would have better reading comprehension achievement in this sample. The result of the present study was consistent with the result of the studies conducted by Ozonder (2015) and Tsujimoto (2015), which showed the positive correlation between students' motivation and foreign language reading. However, the results of this study were also quite different from the results of studies reported by Senturk (2015) and Olmez (2015), which revealed that students' motivation toward reading in English was neutral.

The results from the present study add to the existing body of knowledge that students generally agree that being able to read in English is important for their success in English learning, which can be considered as the positive contribution to their motivation. Additionally, this means that the students see value in improving their reading ability in English. The students preferred to read English text due to being in an effort to contribute to their language development.

In relation to the students' motivation in English learning and their achievement scores in writing skill, it was found that the significance value of students' motivation in English learning and writing skill was 0.756 . This significant value was even higher compared to the significant value between students' motivation and reading skill. It proved that motivation and writing skill had strong relationship. In other words, this significant value showed strong association or accurate prediction that when the students were motivated in English learning, they would have better writing performance particularly in this sample. The result of this study was in line with studies conducted by Hashemian and Heidari (2013) and Shui and Yin (2007) which showed the relationship that motivation mediated students' performance on writing. Nevertheless, a study by William and Alden (1983) was different in that motivated students would not take a writing course if it was not required.

The result is also informative and useful to teachers or educators who are eager to enhance students' motivation in English writing skill. Finally, motivation in English learning has positive correlation to students' literacy skills both in reading and writing skills, with higher correlation shown between students' motivation and writing skill. The positive relationship suggests that if the students feel greater sense of competency, their achievement would be high as well. The 
students with higher levels of motivation tend to have higher levels of achievement than with the lower levels of motivation, and vice versa. This result is also in line with the previous study by Bernaus and Gardner (2008). They stated that motivation was a positive predictor of English achievement. Therefore, it is clear that motivation has direct influence on students' achievement scores in English literacy skills.

\subsection{The relationship between students'scores in reading and writing skills}

The result of this study showed that the significance value of correlation between reading and writing skills was 0.817 . This value was even higher compared to the correlation between motivation and literacy skills. It proved that there was a strong connection between reading and writing skills. This typical range of correlation coefficients might be useful for making prediction that when the students were good in reading comprehension, they also could improve their writing skill. It could be stated that students as the readers and writers enriched their knowledge by receiving and producing information. The result of this study was relevant to that of Carson and Leki (1993) as well as Ferris and Hedgcock (2005) who found that reading can be the basis for writing because the information from reading contains messages as well as clues about how the messages' grammatical, lexical, semantic, and rhetorical combine to make the message meaningful. Next, the result of this study was also consistent with studies conducted by Yoshimura (2009), Zhao and Hirvela (2015), and Alharbi (2015) showing that connecting reading and writing had positive effects on students process and behavior as well as laying the foundation necessary for their work in writing. However, Carson et al. (1990) and Hasani (2012) had different results in that reading and writing were related but the strength differs for each language group.

The results from the present study add to the existing body of knowledge about the importance of connecting reading and writing in language classroom. Students receive various inputs from reading such as content information, organization, and language forms. In general, reading comprehension has positive effects to improve students' writing performance. Therefore, it can be stated that reading is an important component of writing in academic setting that helps students understand and master the skills involved in foreign language writing.

\subsection{The relation of English learning motivation between male and female students}

In this study, the writers try to find out whether gender contributed any difference in motivation in English learning. Table 5 shows the sig. (2-tailed) value was 0.308 (>0.05), meaning that there was no significant difference in English learning motivation between male and female students. The result implied that male and female students' motivation in English learning was at the same level for this sample. It denoted that motivation in English learning did not depend on the students' gender. Although Table 4 showed a sign that female students $(\mathrm{M}=65.40)$ in this sample tended to have higher motivation in English learning than male students $(\mathrm{M}=63.67)$, the difference was not significant. Thus, the result in this sample could not be used as the prediction about motivation in English learning felt by students with different gender. This conforms to the results of number of studies (e.g., Yeung, Lau, \& Nie, 2011; Ozturk \& Gurbuz, 2013; Mori \& Gobel, 2006) that reported both male and female students tended to have the same level of motivation in learning English with higher tendency on female students. Nevertheless, some studies brought different result that the level of motivation in male and female students were significantly different and this difference was in favor of males as they regard the learning process as more connected to their success in their future life (e.g., Ozuturk, 2012; Mahdavy, 2013; Hakan \& Munire, 2014).

All in all, the results of the present study modify the existing knowledge about the relation between motivation among male and female students. The results show the importance of having high motivation to learn English in order to be more successful in students' future life. Therefore, in EFL classroom, teachers should encourage male and female students to be mingled in group discussion in order that they can learn from one another.

\subsection{The relation of literacy skills (reading and writing) scores between male and female students}

In relation to literacy skills and gender, the writers try to find out whether there is a significant difference between literacy skills scores among male and female students. Table 7 presents the sig. (2-tailed) value (0.449) was higher than 0.05 . This means that there was no significant difference between gender and students' literacy skills scores. The result implied that male and female students' scores in literacy skills were similar for this sample. Thus, it could be claimed that literacy skills scores did not depend on the students' gender. As shown in Table 6, although there was a tendency that female students $(M=75.55)$ got higher scores in literacy skills than male students $(M=72.95)$, this difference was not apparent. The result of this study was congruent with the previous studies conducted by Kasiri (2015), Rudzinska (2013), and Babayigit (2015) that presented no significant difference between male and female students in their reading and writing performances. Some studies found the tendency of females outperforms males in literacy skills (e.g., Aliakbari \& Haghighi, 2014; Dabaghi, 2012). Besides the relevant previous studies, some studies also revealed the opposite results (e.g., Gorjian \& Javadifar, 2013; \& Mei, 2012) that male students have better performance than females in reading comprehension test and have higher mean scores in using reading strategies.

All in all, the results of the study emphasize the fact that both male and female students try their best to get high scores in literacy skills. Therefore, in EFL classroom, it is equally challenging to teachers for not favoring male students over females and vice versa. Teachers should also give the same opportunity for students to learn and express their ideas in English. This implies that male and female students have equal chances of acquiring the target language.

\section{Conclusions}

The present study has shown that although there has been contradiction among experts regarding the relation between 
students' motivation in reading and writing skills, the result of this study confirms motivation as one of the important factors affecting students' language learning processes. The high correlation indicates that when the students feel highly motivated in learning English, there is a high possibility for them to have good achievement in reading and writing skills. This study has also shown that when the students get high achievement scores in reading skill, their achievement in writing would be high as well. Furthermore, gender is not shown as a significant variable which may influence the result of language learning. Moreover, gender does not determine students' achievement scores in English literacy skills. It seems that both male and female students have similar ability and the equal chance to get high scores in literacy skills, namely reading and writing skills.

In light of the results of the study, EFL teachers/ lecturers are encouraged to stimulate motivation more frequently in classroom by using any strategy in language learning or by creating more enjoyable learning situation to strengthen students' motivation. Teachers/ lecturers are also suggested to integrate reading comprehension strategies in academic writing tasks. The integrated instructions could lead to a greater understanding and students' better achievements in their English literacy skills.

\section{References}

Alharbi, F. (2015). Writing for learning to improve students' comprehension at college level. English Language Teaching, 8(5).

Aliakbari, M., \& Haghighi, J. K. (2014). On the effectiveness of differentiated instruction in the enhancement of Iranian learners reading comprehension in separate gender education. Procedia-Social and Behavioral Sciences, 98, $182-189$.

Babayigit, S. (2015). The dimensions of written expression: Language group and gender differences. Learning and Instruction, 35, 33-41.

Bernaus. M., \& Gardner, R. C. (2008). Teacher motivation strategies, student perceptions, student motivation, and English achievement. The Modern Language Journal, 92, 387-401.

Brown, H. D. (2007). Teaching by principles ( $3^{\text {rd }}$ ed). White Plains, NY: Pearson Education.

Brown, H. D. (2004). Language assessment principles and classroom practices. White Plains, NY: Pearson Education.

Carson, J. E., Carrell, P. I., Silberstein, S., Kroll, B., \& Kuehn, P. A. (1990). Reading-writing relationship in first and second language. TESOL Quarterly, 24(2).

Carson, J., \& Leki, I. (1993). Reading in the composition classroom: Second language perspective. Boston: Heinle \& Heinle.

Dabaghi, A. (2012). Gender differences in Iranian EFL students' letter writing. International Journal of Applied Linguistics and English Literature, 1(7).

Dietsch, B. M. (2009). Reasoning \& writing well ( $5^{\text {th }}$ ed). New York: McGraw-Hill.

Dornyei, Z. (1998). Motivation in second and foreign language learning. Journal of Cambridge: Language Teaching, 31(3), 117-135.

Dornyei, Z. (2001). Teaching and researching motivation. London: Pearson Education Limited.

Eckert, P., \& Ginet, S. M. (2003). Language and gender. New York: Cambridge University Press.

Elias, H. (2010). Achievement motivation and self-efficacy in relation to adjustment among university students. Journal of Social Sciences, 6(3), 333-339.

Ferris, D. R., \& Hedgcock, J. S. (2005). Teaching ESL composition: Purpose, process, and practice. Mahwah, NJ: Lawrence Erlbaum Associates.

Galko, F. D. (2002). Better writing now: Using words to your advantage. New York: Learning Express.

Gardner, R. C. (1985). Social psychology and second language learning: The role of attitudes and motivation. London: Edward Arnold Publishers.

Gorjian, B., \& Javadifar, M. (2013). Effects of gender and passage content on multiple choice reading comprehension test. Procedia - Social and Behavioral Sciences, 84, 723-727.

Hakan, K., \& Munire, E. (2014). Academic motivation: Gender, domain, and grade differences. Procedia-Social and Behavioral Sciences, 143, 798-715.

Hasani, L. (2012). A study of students' reading performance in two test formats of summary writing and open-ended questions. Procedia-Social and Behavioral Sciences, 69, 915-923.

Hashemian, M., \& Heidari, A. (2013). The relationship between 12 learners' motivation/ attitude and success in 12 writing. Procedia-Social and Behavioral Sciences, 70, 476-489.

Heaton, J. B. (1988). Writing English language test. New York: Longman.

Kasriri, F. (2015). The impact of non-lyrical Iranian traditional music on reading comprehension performance of Iranian EFL learners: The case of gender, attitude, and familiarity. Procedia-Social and Behavioral Sciences, 199, $157-162$.

Lightbown, P. M., \& Spada, N. (2006). How language are learned. Oxford: Oxford University Press. 
Lin, L. F. (2011). Gender differences in 12 comprehension and vocabulary learning in the video-based call program. Journal of Language Teaching and Research, 2(2), 295-301.

Lodico, M. G., Spaulding, D. T., \& Voegtle, K. H. (2010). Methods in educational research. San Francisco: Jossey-Bass. Mahdavy, B. (2013). Gender and motivational orientations of English language learners: The case of high school students in Iran. Procedia-Social and Behavioral Sciences, 70, 1056-1061.

Mahmud, M. (2010). Language and gender in English language teaching. TEFLIN Journal, 21(2), 172-185.

Mei, L, L. (2012). A study of the selection of reading strategies among genders by EFL college students. ProcediaSocial and Behavioral Sciences, 64, 310-319.

Mistar, J. (2014). Strategies of learning speaking ability by Indonesian learners of English and their contribution to speaking proficiency. TEFLIN Journal, 25(2), 203-216.

Mobarakeh, S. (2014). Teachers' feedback and students' motivation in English for general and specific purposes courses in Iran. Theory and Practice in Language Studies, 4(5), 973-981.

Mori, S., \& Gobel, P. (2006). Motivation and gender in the Japanese EFL classroom. System, 34, 194-210.

Murcia, C. (2001). Teaching English as a second or foreign language. New York: Heinle \& Heinle, Thompson Learning.

Olmez, F. (2015). An investigation into the relationship between 12 reading motivation and reading achievement. Procedia-Social and Behavioral Sciences, 199, 597-603.

Ozonder, O. (2015). Prospective ELT students' foreign language reading attitudes and motivation. Procedia-Social and Behavioral Sciences, 199, 722-729.

Ozuturk, G. (2012). To what extent are postgraduate international students at Sunderland university intrinsically motivated in learning English? and is there a difference between male and female students in terms of their intrinsic motivation?. Procedia-Social and Behavioral Sciences, 46, 424-430.

Oztruk, G., \& Gurbuz, N. (2013). The impact of gender on foreign language speaking anxiety and motivation. ProcediaSocial and Behavioral Sciences, 70, 654-665.

Rudzinska, I. (2013). Are females better than males in communication in second language?. Journal of Education Culture and Society, 2, 148-154.

Schunk, D. H., Pintrich, P. R., \& Meece. (2008). Motivation in education: Theory, research, and applications (3 $3^{\text {rd }}$ ed). Upper Saddle River, NJ: Pearson Education.

Senturk, B. (2015). EFL Turkish university students' attitudes and motivation towards reading in English. ProcediaSocial and Behavioral Sciences, 199, 704-712.

Shui, F. M., \& Yin, K. L. (2007). The roles of instructional practices and motivation in writing performance. The Journal of Experimental Education, 75(2), 145-164.

Tahriri, A. (2011). Male and female EFL learners' self-perceived strategy use across various educational levels: A case study. English Language Teaching, 4(4), 181-194.

Toni, A. (2012). Overall motivation and the promotion of EFL learners' oral proficiency. Theory and Practice in Language Studies, 2(11), 2336-2341.

Tsujimoto, K. (2015). Motivation and reading achievement: Understanding the needs and motivation processes of adult literacy learners. Published Article. Ontario: Brock University

What is literacy? An investigation into definition of English as a subject and the relationship between English, literacy, and being literate. A Research Report Commissioned by Cambridge Assessment. (2013). (Online). Available: http://www.cambridgeassessment.org.uk, retrieved on February $20^{\text {th }}, 2015$.

Williams, J. D., \& Alden, S. D. (1983). Motivation in the composition class. Research in the Teaching of English, 17(2).

Williams, M., \& Burden, R.L. (1997). Psychology for language teachers: A social constructivist approach. Cambridge: Cambridge University Press.

$\mathrm{Xu}, \mathrm{X}$. (2011). The relationship between language learning motivation and the choice of language learning strategies among Chinese graduates. International Journal of English Linguistics, 1(2), 203-212.

Yeung, A.S., Lau, S., \& Nie, Y. (2011). Primary and secondary students' motivation in learning English: Grade and gender differences. Contemporary Educational Psychology, 36, 246-256.

Yoshimura, F. (2009). Effects of connecting reading and writing and a checklist to guide the reading process on EFL learners' learning about English writing. Procedia-Social and Behavioral Sciences, 1, 187-1883.

Zhao, R., \& Hirvela, A. (2015). Undergraduate ESL students' engagement in academic reading and writing in learning to write a synthesis paper. Reading in a Foreign Language, 27(2), 219-241. 


\section{Questionnaire on Motivation in English Learning}

Name:

Age:

Sex:

Address:

Phone number:
Date:

Class:

Semester:

How long have you been studying English:

E-mail:

\section{Questionnaire}

Direction: Here are statements regarding your motivation in English learning. Please read the following statements carefully, and decide how strongly you agree or disagree with them by ticking $(\sqrt{ })$ the corresponding box that tells the degree of your motivation. Note that there is no right or wrong answer to any items of the questionnaire. Please be honest with all your responses. (1=Strongly Disagree; $2=$ Disagree; $3=$ Agree; $4=$ Strongly Agree).

\begin{tabular}{|c|c|c|c|c|c|}
\hline No. & Questions & 4 & 3 & 2 & 1 \\
\hline 1. & I prefer to use English inside and outside the class & & & & \\
\hline 2. & I have curiosity in English literature such as poetry, prose, or drama & & & & \\
\hline 3. & I have strong desire to know all aspects in English & & & & \\
\hline 4. & Reading and writing is easy for me & & & & \\
\hline 5. & I am confident during the English lectures & & & & \\
\hline 6. & I would like to have challenging exercises during learning English & & & & \\
\hline 7. & During English class, I would like to have lots of activities to actively participate & & & & \\
\hline 8. & I am cooperative in doing pairs or group works during English class & & & & \\
\hline 9. & I actively finish class project/ follow-up activities & & & & \\
\hline 10. & During English class, I easily understand the audio recording & & & & \\
\hline 11. & During English class, I am confident to use English in monolog or dialogue & & & & \\
\hline 12. & During English class, I easily understand paragraphs/ texts & & & & \\
\hline 13. & When I am in English discussion, I volunteer answer as much as possible & & & & \\
\hline 14. & English lecturer is a great source of inspiration in class & & & & \\
\hline 15. & I am studying English because I think it will enable me to get highly paid-job & & & & \\
\hline 16. & I am studying English because I can get reward from parents/ family & & & & \\
\hline 17. & $\begin{array}{l}\text { I am studying English because I want to earn university degree and good job } \\
\text { rather than learning the language itself }\end{array}$ & & & & \\
\hline 18. & $\begin{array}{l}\text { I am studying English because being proficient in English can lead to more } \\
\text { success and achievement in life }\end{array}$ & & & & \\
\hline 19. & $\begin{array}{l}\text { I am studying English because being proficient in English are in very high respect } \\
\text { in my country }\end{array}$ & & & & \\
\hline 20. & $\begin{array}{l}\text { I am studying English because I want to participate freely in academic, social, and } \\
\text { professional activities among other cultural groups }\end{array}$ & & & & \\
\hline 21. & $\begin{array}{l}\text { I am studying English because I want to travel or live in English-speaking } \\
\text { countries }\end{array}$ & & & & \\
\hline 22. & $\begin{array}{l}\text { I am studying English because it is a potential knowledge for development in the } \\
\text { future }\end{array}$ & & & & \\
\hline 23. & I read textbooks only for university study, not other English texts. & & & & \\
\hline 24. & $\begin{array}{l}\text { I am able to understand English movies, pop music, and other programs on } \\
\text { satellite TV }\end{array}$ & & & & \\
\hline 25. & I am studying English because it is a worldwide trend & & & & \\
\hline
\end{tabular}

